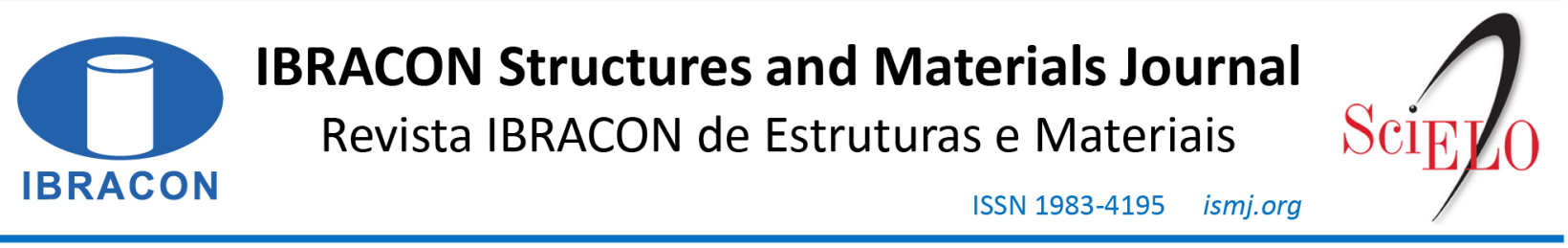

ORIGINAL ARTICLE

\title{
Correlation between concrete strength properties and surface electrical resistivity
}

\section{Correlação entre as propriedades de resistência do concreto e a resistividade elétrica superficial \\ Carla Cavalcante Araújo ${ }^{\text {a }}$ \\ Gibson Rocha Meira ${ }^{\mathrm{a}, \mathrm{b}}$ (D)

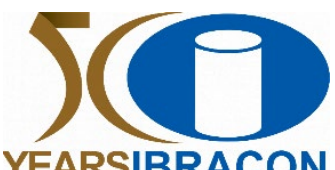

${ }^{a}$ Universidade Federal de Paraíba - UFPB, Civil and Environmental Engineering Post-Graduate Program, João Pessoa, PB, Brasil

bInstituto Federal da Paraíba, Science and Technology of Paraíba - IFPB, João Pessoa, PB, Brasil

Received 27 August 2020

Accepted 18 April 2021

\begin{abstract}
Periodic inspections in reinforced concrete structures are important to be carried out to assess their state of conservation. In this scenario, non-destructive tests can be a suitable option since destructive tests are invasive and may be difficult to be performed in some cases. Considering this option, correlations between nondestructive test parameters and the concrete properties to be analyzed are useful tools that make easier the structure inspection. In the present work, correlations between the compressive strength $\left(f_{c}\right)$ and splitting tensile strength $\left(f_{t}\right)$ and surface electrical resistivity $(\rho)$ of concretes were studied. Brazilian concretes of six different mixtures were analyzed at five different ages and correlation curves between strength properties and surface electrical resistivity of concrete were obtained, which are represented by the general relationships $\mathrm{f}_{\mathrm{c}}=14 \cdot 18 \cdot \ln (\rho)$ +18.43 and $\mathrm{f}_{\mathrm{t}}=0.69 \cdot \ln (\rho)+2.15$ for compressive strength and splitting tensile strength, respectively. In addition, a general curve considering literature data and results from this work was proposed to represent the relationship between compressive strength and surface electrical resistivity $-f_{c}=11.89 \cdot \ln (\rho)+18.90$.
\end{abstract}

Keywords: concrete, compressive strength, electrical properties, non-destructive testing, tensile properties.

\begin{abstract}
Resumo: A realização de inspeções periódicas em estruturas de concreto armado é importante para a avaliação do seu estado de conservação. Neste cenário, ensaios não destrutivos podem ser uma opção adequada, uma vez que os testes destrutivos são invasivos e, em alguns casos, podem ser difíceis de serem realizados. Considerando essa opção, correlações entre parâmetros de ensaio não destrutivos e propriedades do concreto a serem analisadas são ferramentas úteis que facilitam a inspeção da estrutura. No presente trabalho, foram estudadas correlações entre a resistência à compressão $\left(f_{c}\right)$, a resistência à tração por compressão diametral $\left(f_{t}\right)$ e a resistividade elétrica superficial $(\rho)$ de concretos. Concretos brasileiros com seis traços distintos foram analisados em cinco idades diferentes e foram obtidas curvas de correlação entre propriedades de resistência e resistividade elétrica superficial do concreto, as quais são representadas pelas relações gerais $\mathrm{f}_{\mathrm{c}}=14,18 \cdot \ln (\rho)+18,43$ e $\mathrm{f}_{\mathrm{t}}=0,69 \cdot \ln (\rho)+2,15$ para resistência à compressão e resistência à tração por compressão diametral, respectivamente. Além disso, foi proposta uma curva geral, considerando dados da literatura e resultados deste trabalho, para representar a relação entre a resistência à compressão e a resistividade elétrica superficial $-\mathrm{f}_{\mathrm{c}}=11,89 \cdot \ln (\rho)+18,90$.
\end{abstract}

Palavras-chave: concreto, resistência à compressão, propriedades elétricas, ensaios não destrutivos, propriedades de tração.

How to cite: C. C. Araújo, and G. R. Meira, "Correlation between concrete strength properties and surface electrical resistivity," Rev. IBRACON Estrut. Mater., vol. 15, no. 1, e15103, 2022, https://doi.org/10.1590/S1983-41952022000100003

\section{INTRODUCTION}

Environmental aggressiveness associated with deficiencies in the quality of concrete structures has been causing, prematurely, loss of performance of reinforced concrete structures. In order to evaluate the state of conservation and

Corresponding author: Gibson Meira. E-mail: gibsonmeira@yahoo.com, gibson.meira@ifpb.edu.br

Financial support: Coordination for the Improvement of Higher Education Personnel (CAPES).

Conflict of interest: Nothing to declare. 
carry out preventive maintenance of these structures, periodic inspections are needed. In this scenario, non-destructive tests (NDT) are an important tool for this kind of inspection and help on a more suitable analysis of the structure [1].

Considering the concrete structure degradation condition, destructive tests may be infeasible or bring risks to the structure. Differently, NDT offer significant advantages with respect to its quick response, lower cost, absence of damage risk to the structure damage, immediate availability of results and the easiness of taking as more measurements as necessary [2].

Regarding the use of NDT for concrete structures inspection, correlations between NDT parameters and the concrete properties to be analyzed are necessary and make easier the analysis of structures inspection data. However, it is recommended that if there is a significant change in the materials characteristics, a new correlation should be established to provide greater reliability for the estimated property [3]. In this scenario, there are available NDT that can be used to evaluate some concrete properties, such as their compressive strength, modulus of elasticity and durability parameters [4].

One of the most studied concrete properties associated with NDT is the compressive strength, which is linked to the structural safety. On the other hand, sclerometry and ultrasonic pulse velocity (UPV) tests are NDT widely used to evaluate reinforced concrete structures. As a result, there are already several studies that propose correlation curves between these last tests and compressive strength, both individually and by the combination of these non-destructive tests [1], [5], [6].

Surface electrical resistivity of concrete is a property measured by a NDT and it is closely related to the concrete microstructure. It is used to evaluate the concrete resistance to the chloride penetration and to the carbonation front advance, which are the main causes of reinforcement corrosion. However, there are few studies that suggest other applications for the surface electrical resistivity test. Some authors, such as Lübeck et al. [7], Chen et al. [8], Bem et al. [9] and Mendes et al. [10], observed that the concrete resistivity increases as the compressive strength increases, whereas Medeiros-Junior and Lima [11] report that electrical resistivity measurements can be used to predict the compressive strength of Portland cement pastes.

For this reason, it is expected that the surface electrical resistivity test can be used to estimate the compressive strength and tensile strength of concrete due to the test susceptibility to variations in the materials microstructure, as well as the fact that these concrete properties increase with the progress of the cement hydration. Besides that, although the relation between tensile strength and compressive was already widely studied [12-14] and follows a power function [12-17], the surface electrical resistivity can be introduced in this scenario and generate a new approach on this last relation, considering these three variables.

Regarding the few studies that focused on the relationship between compressive strength of concrete and its surface electrical resistivity, and the absence of studies focused on the relationship between this electrical property and concrete tensile strength, this work aimed to analyze the possible correlations between compressive and splitting tensile strength and surface electrical resistivity for concretes ranged between 30 and $50 \mathrm{MPa}$ of compressive strength. A new approach on the relationship between tensile strength and compressive strength considering the surface electrical resistivity was also presented.

\section{SURFACE ELECTRICAL RESISTIVITY OF CONCRETE}

\subsection{General aspects}

Electrical resistivity can be defined as the ability of a material to withstand the electrical current passage. Therefore, resistivity is the inverse of conductivity [9]. In the concrete, electrical resistivity is a property that characterizes the difficulty with which the ions move in the concrete aqueous phase, subjected to an electrical field [18]. Consequently, resistivity is a parameter that is related to the transport of aggressive agents into concrete, such as chloride ions and carbon dioxide [11]. A low value of electrical resistivity is generally correlated with a high chloride penetration rate or with a high rate of carbonation front advance and, consequently, a greater susceptibility to reinforcement corrosion. That is, the higher the concrete electrical resistivity is, the greater its resistance to the penetration of aggressive agents [19]. RILEM TC 154-EMC [19] report that depending on how the concrete resistivity is measured, different information will be obtained. The apparent electrical resistivity is obtained in the case of the surface electrical resistivity measurements on concrete. Volumetric resistivity is obtained when measurements are made through a concrete mass.

The volumetric electrical resistivity test is standardized in some countries [20]-[22] and is based on the measurement of the resistance between two electrodes (in general plates) positioned on concrete opposite surfaces. However, it can present some complexity for assembling the test cell and has limitation to be used on site [23].

The test that measures surface electrical resistivity was originally developed by geologists to measure soil resistivity [24]. This method was adapted for use in concrete by means of a similar apparatus, which adopts a probe with four equally spaced electrodes set up in a linear array and put in contact with the concrete surface. It is called the 
four-point method or Wenner method [24], [25]. This property is measured by reading the electrical current between the outer electrodes and the potential difference between the inner electrodes placed on the concrete surface [23].

Additionally, other techniques have been developed and adapted for both the measurement of surface electrical resistivity (in real structures and in specimens used in laboratory experiments), such as the surface disc test, and the bulk electrical resistivity measurement, which differ in terms of the number of used electrodes and their positioning on the concrete surface [19], [26]. However, Wenner method is still the one widely used.

The surface electrical resistivity test can be considered an important tool to be used to verify concrete quality and in service life analysis of concrete structures, since it can be correlated with different properties of the material, such as the resistance for transporting chloride ions, moisture content, degree of cement paste hydration, corrosion probability, Young's modulus and compressive strength [9], [27].

In relation to the compressive strength property, the literature shows some studies that analyzed the relationship between surface electrical resistivity and compressive strength, through the attainment of correlation curves [28]. However, similar relationship analysis considering the tensile strength were not identified in literature.

Andrade and D'Andrea [27], Wei et al. [29] and Medeiros-Junior et al. [11], Bem et al. [9] are researchers that, although their main objective was to study the influence of different factors on surface electrical resistivity measurements, they also obtained correlation curves between compressive strength and surface electrical resistivity (Table 1), which are mainly represented by logarithmic functions.

Table 1. Correlation curves between compressive strength $\left(f_{c}\right)$ and surface electrical resistivity $(\rho)$ for cementitious materials literature data.

\begin{tabular}{|c|c|c|c|c|c|c|}
\hline Author & Equation & $\begin{array}{l}\text { Determination } \\
\text { coefficient }\left(\mathbf{r}^{2}\right)\end{array}$ & Specimens & $\begin{array}{c}\text { Cement } \\
\text { type }\end{array}$ & $\begin{array}{l}\text { Age of test } \\
\text { (days) }\end{array}$ & $\begin{array}{c}\begin{array}{c}\text { Additional } \\
\text { information }\end{array} \\
\end{array}$ \\
\hline $\begin{array}{c}\text { Andrade and D'Andrea (2011) } \\
\text { [27] }\end{array}$ & $f_{c}=6.897 \cdot \ln (\rho)+6.827$ & N.I. & $\begin{array}{l}\text { Concrete cylinders } \\
(150 \mathrm{~mm} \times 300 \mathrm{~mm})\end{array}$ & N.I. & N.I. & $\begin{array}{c}\text { Four-point method } \\
\text { (Wenner method) / } \\
\rho \text { by } \Omega \cdot \mathrm{m} .\end{array}$ \\
\hline \multirow[b]{2}{*}{$\begin{array}{l}\text { Ramezanianpour et al. } \\
\text { (2011) [30] }\end{array}$} & $f_{c}=3.587 \rho-9.186$ & 0.87 & \multirow{2}{*}{$\begin{array}{c}\text { Concrete cylinders } \\
(100 \mathrm{~mm} \times 200 \mathrm{~mm}) \\
\text { and concrete cubes } \\
\text { with } 100 \mathrm{~mm} \text { of } \\
\text { edges }\end{array}$} & \multirow[b]{2}{*}{ OPC } & \multirow[b]{2}{*}{728} & \multirow{2}{*}{$\begin{array}{c}\text { Four-point method } \\
\text { (Wenner method)/ } \\
\rho \text { by } \\
\mathrm{k} \Omega \cdot \mathrm{cm} \Omega \cdot \mathrm{cm} \Omega \cdot \mathrm{cm} .\end{array}$} \\
\hline & $f_{c}=33.58 \cdot \ln (\rho)-27.28$ & 0.88 & & & & \\
\hline \multirow[b]{2}{*}{ Wei et al. (2012) [29] } & \multirow[b]{2}{*}{$\mathrm{f}_{\mathrm{c} 28}=8.76 .\left(\rho_{24 h}\right)+20.4$} & \multirow[b]{2}{*}{0.963} & \multirow[b]{2}{*}{ N.I } & \multirow[b]{2}{*}{ N.I. } & $28-f_{c}$ & \multirow{2}{*}{$\begin{array}{c}\text { Electrical } \\
\text { resistivity of } \\
\text { cement paste in the } \\
\text { fresh state } \\
\text { measured by a } \\
\text { non-contact } \\
\text { device } / \rho \text { by } \Omega \cdot \mathrm{m} \text {. }\end{array}$} \\
\hline & & & & & $1-\rho$ & \\
\hline \multirow{8}{*}{$\begin{array}{l}\text { Medeiros-Junior et al. } \\
\text { (2014) [31] }\end{array}$} & $\mathrm{f}_{\mathrm{c}}=21.24 \cdot \ln (\rho)+11.20$ & 0.823 & \multirow{8}{*}{$\begin{array}{l}\text { Concrete cylinders } \\
(100 \mathrm{~mm} \times 200 \mathrm{~mm}) \\
\text { and concrete cubes } \\
\text { with } 250 \mathrm{~mm} \text { of } \\
\text { edges }\end{array}$} & \multirow{2}{*}{ FPC } & 28 & \multirow{8}{*}{$\begin{array}{c}\text { Four-point method } \\
\text { (Wenner method) } \\
\rho \text { by } \mathrm{k} \Omega \cdot \mathrm{cm} .\end{array}$} \\
\hline & $f_{c}=49.05 \cdot \ln (\rho)-43.03$ & 0.995 & & & 91 & \\
\hline & $f_{c}=32.34 \cdot \ln (\rho)-68.97$ & 0.997 & & \multirow{4}{*}{ PPC } & 28 & \\
\hline & $f_{c}=65.36 \cdot \ln (\rho)-208.67$ & 0.995 & & & 91 & \\
\hline & $f_{c}=41.50 \cdot \ln (\rho)-61.38$ & 0.999 & & & 28 & \\
\hline & $f_{c}=70.34 \cdot \ln (\rho)-175.80$ & 0.993 & & & 91 & \\
\hline & $\mathrm{f}_{\mathrm{c}}=14.66 \cdot \ln (\rho)+23.29$ & 0.992 & & \multirow{2}{*}{ HSPC } & 28 & \\
\hline & $f_{c}=32.28 \cdot \ln (\rho)-6.92$ & 0.999 & & & 91 & \\
\hline Bem et al. (2018) [9] & $f_{c}=21.49 \cdot \ln (\rho)-2.71$ & 0.81 & $\begin{array}{l}\text { Concrete cylinders } \\
(100 \mathrm{~mm} \text { x } 200 \mathrm{~mm})\end{array}$ & FPC & 28 & $\begin{array}{c}\text { Four-point method } \\
\text { (Wenner method) / } \\
\rho \text { by } \mathrm{k} \Omega \cdot \mathrm{cm} .\end{array}$ \\
\hline Sabbağ and Uyanik (2018) [28] & $f_{c}=57.2 \cdot \ln (\rho)-84.3$ & 0.92 & $\begin{array}{l}\text { Unreinforced and } \\
\text { reinforced cubes } \\
(150 \times 150 \times 150 \mathrm{~mm})\end{array}$ & FPC & $7-90$ & $\begin{array}{c}\text { Four-point method } \\
\text { (Wenner method)/ } \\
\rho \text { by } \mathrm{k} \Omega \cdot \mathrm{cm} .\end{array}$ \\
\hline
\end{tabular}

N.I. - Not informed $\mathrm{f}_{\mathrm{c}}$ - Compressive strength $\rho$-Surface electrical resistivity

OPC - Portland plain cement FPC - Filler modified Portland cement $\quad$ PSC - Portland slag cement

PPC - Portland pozzolan cement HSPC - High early strength Portland cement 


\subsection{Influencing parameters}

Wenner method is a non-destructive test with a simple operation procedure, thorough which the generated data are immediately obtained. On the other hand, it is affected by some factors such as the moisture content of concrete. Therefore, measurements of surface electrical resistivity must be performed under certain humidity and temperature conditions, as well as meet some geometric criteria in relation to the tested surface.

Among all influencing factors, the moisture content is one of the most important variables, because the electric current that passes through the concrete is driven by the aqueous solution in the pores. In this sense, Chen et al. [8] verified that the electrical resistivity measurements on dry specimens, which were in the oven or in the air with $40 \%$ of relative humidity, were unstable or even undetected. On the other hand, these measurements in specimens in the saturated dry surface or saturated wet surface condition had similar resistivity values. Therefore, it is suggested that the samples should be wetted prior to resistivity measurements, in particular to correlate these measurements with concrete properties.

Some papers report that temperature changes have certain effects on concrete resistivity. When temperature increases, the electrons move faster, increasing conductivity, thus reducing electrical resistivity considering a constant humidity level [7], [26]. Therefore, to eliminate the effect of temperature on surface electrical resistivity measurements, most laboratory studies are performed in environments with controlled temperature, usually between $20^{\circ} \mathrm{C}$ and $25^{\circ} \mathrm{C}[26]$.

In Wenner method, electrical resistivity measurements are performed considering a semi-infinite and homogeneous medium. This fact leads to a distortion in the measured values, since concrete is a heterogeneous material and the cylindrical or prismatic specimens have a relatively small size, diverging from the ideal condition of having an infinitely large geometry. To rectify this kind of distortion, a correction is suggested. The data from surface electrical resistivity measurements from cylindrical or prismatic specimens must be multiplied by a geometric correction factor [27], [32].

Regarding the limited size of the specimens, the spacing between the electrodes must be adjusted to avoid electrodes near the ends of the specimens. Spacing between electrodes ranging from 3 to 5 centimeters are usual [19]. Otherwise, the electric current may flow not only through the concrete specimen, but also through air at its edges, resulting in overestimated resistivity values, because air is always more resistant than concrete [33].

The electrical resistivity measurements are also influenced by the concrete mixtures. Considering the $\mathrm{w} / \mathrm{c}$ ratio, the resistivity values decrease as the $\mathrm{w} / \mathrm{c}$ ratio increases. This behavior can be explained by the fact that the aqueous solution in the concrete porous network acts as a conductive media [31]. Thus, concretes with a higher w/c ratio have greater porosity and, therefore, the possibility of greater presence of water in their porous network. Taking into account the type of cement, concretes manufactured with Portland-slag cement (ASTM Type IS) have higher resistivity compared to Portland-pozzolan cement (ASTM Type IP) and high early strength Portland cement (ASTM type III). This behavior is related to the pore refinement effect and reduction of concrete permeability, due to the significant amount of mineral additions [7], [31]. Considering the amount of coarse aggregate, the aggregates have a higher electrical resistivity compared to the hardened cement paste. Sengul [34] and Hou et al. [35] observed that the increase in aggregate amount and the reduction in cement paste content for a given volume of concrete resulted in higher resistivity values due to the replacement of cement paste by coarse aggregates.

\section{MATERIALS AND EXPERIMENTAL PROGRAM}

This work used concretes from two suppliers of ready-mix concrete, which are here identified as A and B concrete families. Concretes from three different compressive strength classes were used, which should belong to C30 (30 MPa), $\mathrm{C} 40$ (40 MPa) and C50 (50 MPa) classes.

The present research was divided in three steps. The first step consisted in the characterization of the materials used on concretes production (fine aggregates, coarse aggregates and cements). The second step comprised the casting of the concrete specimens, the wet curing for seven days, the conducting of the surface electrical resistivity test and the evaluation of the compressive and splitting tensile strengths. The last three tests were performed at five concrete ages $(3,7,28,90$ and 120 days). The third step consisted in data treatment and analysis.

\subsection{Materials characterization}

In relation to the fine aggregate, A concretes family used two types of sand (here called AS1 and AS2 sands) and B concretes family used a single type of sand (here called BS1 sand). Regarding the coarse aggregates, A and B concretes used two types of gravel (here referred to as AG1 and AG2 gravels for A concretes family, and BG1 and BG2 gravels for B concretes family).

These aggregates were characterized in regard to particle size distribution, bulk density, specific density for fine aggregate, specific density for coarse aggregate and powder material (fine material passing through the $75 \mu \mathrm{m}$ sieve 
per wash), following the recommendations of Brazilian standards NBR NM 248 [36], NBR NM 45 [37], NBR NM 52 [38], NBR NM 53 [39] and NBR NM 46 [40], respectively.

A and B concrete families used the same type of cement, Brazilian Portland cement of high early strength (ASTM type III). However, they were obtained from different cement plants. For this reason, they are called here as A and B cements, respectively. These cements were characterized in relation to their specific weight and Blaine specific surface, following the recommendations of Brazilian standards NBR 16605 [41] and NBR 16372 [42], respectively. Furthermore, the cements were also characterized in relation to their chemical composition, by X-ray fluorescence (XRF), and granulometric distribution by the laser diffraction granulometry test.

\subsection{Concrete specimens and tests}

The casting of cylindrical specimens was performed at the construction site, according to guidelines contained in the Brazilian standard NBR 5738 [43]. The specimens were demolded after 24 hours and then cured in lime-saturated water until the age of 7 days. Thirty-two cylindrical specimens with $10 \mathrm{~cm}$ in diameter and $20 \mathrm{~cm}$ in height were cast at the same moment for each concrete mixture, totalizing 192 specimens.

Each concrete mixture used in the casting of the specimens was collected from a single concrete mixer truck during the discharge operation, after removal of the first $15 \%$ and before the discharge of $85 \%$ of the total volume was completed, according to the Brazilian standard NBR NM 33 [44].

The surface electrical resistivity, compressive strength and splitting tensile strength tests were performed at the ages of 3, 7, 28, 90 and 120 days in each concrete mixture, with three specimens being tested at each age. The non-destructive tests were carried out on the same cylindrical specimens used for compressive and splitting tensile strength tests, just before they were tested. Furthermore, two additional specimens of each concrete mixture were also used only for resistivity tests. Thus, the evolution of this property over time could be analyzed based on the same specimens.

The surface electrical resistivity test adopted was the Wenner method (four-point method) and it was performed following the RILEM TC 154-EMC recommendations [19]. Each cylindrical specimen was tested on a saturated dry surface condition, following RILEM TC 154-EMC [19] and Chen et al. [8] recommendations. Three centimeters spacing between electrodes was used to avoid the edge effect. Moreover, a geometric correction factor was also adopted to correct the data provided by the equipment.

Considering the cylindrical shape and dimensions of the specimens, the value used for correcting the measured data was based on recommendations proposed by Morris et al. [32] and UNE 83988-2 [45]. Eight resistivity measures were performed on the lateral surface of each specimen, with an MKII resistivity meter from CNS Farnell. Then, the mean and standard deviation of the measurements were obtained. Figure 1 shows the experimental arrangement of the tests on the cylindrical specimens.

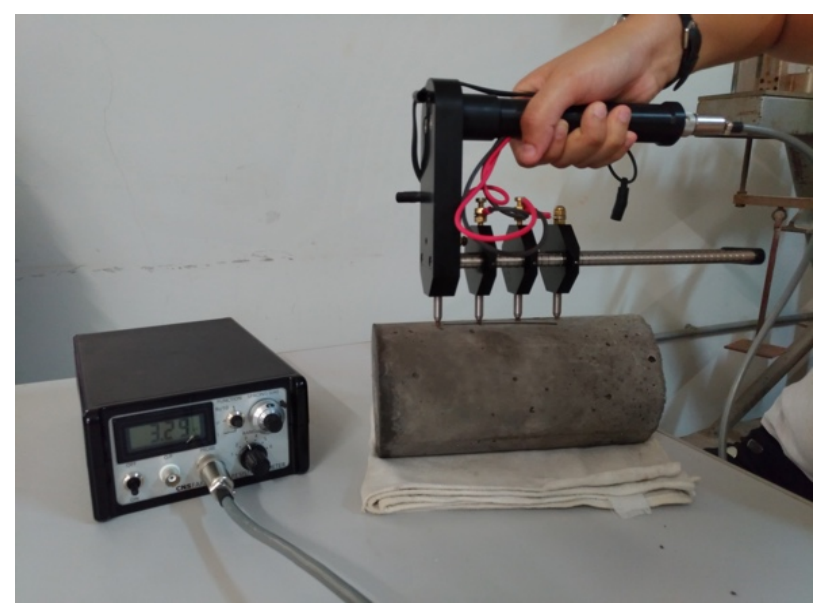

Figure 1. Surface electrical resistivity test by Wenner method in a cylindrical specimen.

Compressive strength was measured in accordance with the guidelines of the Brazilian standard NBR 5739 [46]. During the rupture of all cylindrical specimens, a confined neoprene cushion of $10 \mathrm{~cm}$ in diameter and $1 \mathrm{~cm}$ thick, with 68 shore A hardness, was used. Tensile strength was obtained by splitting tension test, following the Brazilian standard NBR 7222 [47] recommendations. 


\section{RESULTS AND DISCUSSION}

\subsection{Materials characterization}

Table 2 presents the physical characteristics of fine aggregates. All the characteristics presented by the fine aggregates meet the requirements of the Brazilian standards adopted in this work.

Table 2. Physical characteristics of fine aggregates.

\begin{tabular}{|c|c|c|c|c|c|}
\hline Code & Maximum diameter (mm) & Fineness module & Specific density $\left(\mathrm{g} / \mathrm{cm}^{3}\right)$ & Bulk density $\left(\mathrm{g} / \mathrm{cm}^{3}\right)$ & Powder material (\%) \\
\hline AS1 & 2.36 & 1.88 & 2.64 & 1.61 & 3.59 \\
\hline AS2 & 2.36 & 1.98 & 2.67 & 1.71 & 4.53 \\
\hline BS1 & 1.18 & 1.96 & 2.62 & 1.56 & 2.21 \\
\hline
\end{tabular}

Table 3 presents the physical characteristics of coarse aggregates. Table 3 shows that the coarse aggregate AG1 could not be classified in any size distribution interval, due to the excessive presence of fine materials observed in its granulometry test. This situation was confirmed by its high percentage of powder material $(4.76 \%)$, which is much higher than the maximum acceptable limit for coarse aggregates, which is $1 \%$, according to the Brazilian standard NBR 7211 [48]. Except for AG1 gravel, all other gravels presented values of physical characteristics that meet the requirements of the Brazilian standards adopted in this work.

Table 3. Physical characteristics of coarse aggregates.

\begin{tabular}{|c|c|c|c|c|c|c|}
\hline Code & $\begin{array}{c}\text { Size distribution } \\
\text { interval }(\mathrm{mm} / \mathrm{mm})\end{array}$ & $\begin{array}{c}\text { Maximum } \\
\text { diameter }(\mathrm{mm})\end{array}$ & Fineness module & $\begin{array}{l}\text { Specific density } \\
\qquad\left(\mathrm{g} / \mathrm{cm}^{3}\right)\end{array}$ & $\begin{array}{l}\text { Bulk density } \\
\quad\left(\mathrm{g} / \mathrm{cm}^{3}\right)\end{array}$ & $\begin{array}{c}\text { Powder material } \\
(\%)\end{array}$ \\
\hline AG1 & - & 12.50 & 5.34 & 2.77 & 1.65 & 4.76 \\
\hline $\mathrm{AG} 2$ & $9.5 / 25$ & 25.00 & 8.50 & 2.78 & 1.52 & 0.42 \\
\hline BG1 & $4.75 / 12.5$ & 12.50 & 7.00 & 2.76 & 1.43 & 0.34 \\
\hline BG2 & $9.5 / 25$ & 25.00 & 9.10 & 2.77 & 1.46 & 0.12 \\
\hline
\end{tabular}

Chemical and physical characteristics of the used cements are presented in Table 4. By means of the values of the Blaine specific surface in Table 4 and the analysis of Figure 2, in which the granulometric distribution curves obtained by the laser diffraction granulometry test are presented, it is noted that the A cement is slightly finer grained than B cement. Chemical analysis demonstrates that in relation to the major oxide components, the respective amounts are quite close. As a result, it can be accepted that the cements are chemically similar.

Table 4. Chemical composition and physical properties of cements.

\begin{tabular}{|c|c|c|c|}
\hline \multicolumn{2}{|r|}{ Analyzed characteristics } & \multirow{2}{*}{$\begin{array}{c}\text { A Cement } \\
59.33 \%\end{array}$} & \multirow{2}{*}{$\frac{\text { B Cement }}{58.51 \%}$} \\
\hline \multirow{17}{*}{$\begin{array}{l}\text { Chemical composition } \\
(\%) \text { XRF }\end{array}$} & Calcium oxide $(\mathrm{CaO})$ & & \\
\hline & Silicon dioxide $\left(\mathrm{SiO}_{2}\right)$ & $24.99 \%$ & $25.49 \%$ \\
\hline & Ferric oxide $\left(\mathrm{Fe}_{2} \mathrm{O}_{3}\right)$ & $4.05 \%$ & $5.89 \%$ \\
\hline & Aluminum oxide $\left(\mathrm{Al}_{2} \mathrm{O}_{3}\right)$ & $3.91 \%$ & $4.55 \%$ \\
\hline & Sulfuric oxide (SO) & $3.76 \%$ & $2.42 \%$ \\
\hline & Magnesium oxide (MgO) & $2.33 \%$ & $1.98 \%$ \\
\hline & Phosphorus pentoxide $\left(\mathrm{P}_{2} \mathrm{O}_{5}\right)$ & $0.48 \%$ & $0.03 \%$ \\
\hline & Titanium dioxide $\left(\mathrm{TiO}_{2}\right)$ & $0.46 \%$ & $0.44 \%$ \\
\hline & Sodium oxide $\left(\mathrm{Na}_{2} \mathrm{O}\right)$ & $0.33 \%$ & $0.28 \%$ \\
\hline & Potassium oxide $\left(\mathrm{K}_{2} \mathrm{O}\right)$ & $0.33 \%$ & $0.20 \%$ \\
\hline & Strontium oxide (SrO) & $0.10 \%$ & $0.04 \%$ \\
\hline & Manganese oxide $(\mathrm{MnO})$ & $0.04 \%$ & $0.14 \%$ \\
\hline & Chloride $(\mathrm{Cl})$ & $0.03 \%$ & - \\
\hline & Chromium oxide $\left(\mathrm{Cr}_{2} \mathrm{O}_{3}\right)$ & $0.03 \%$ & - \\
\hline & Zinc Oxide $(\mathrm{ZnO})$ & $0.02 \%$ & - \\
\hline & Zirconium dioxide $\left(\mathrm{ZrO}_{2}\right)$ & - & $0.02 \%$ \\
\hline & Nickel oxide $(\mathrm{NiO})$ & - & $0.02 \%$ \\
\hline & Specific weight $\left(\mathrm{g} / \mathrm{cm}^{3}\right)$ & 3.07 & 3.08 \\
\hline & Blaine specific surface $\left(\mathrm{cm}^{2} / \mathrm{g}\right)$ & 3855.63 & 3377.34 \\
\hline
\end{tabular}




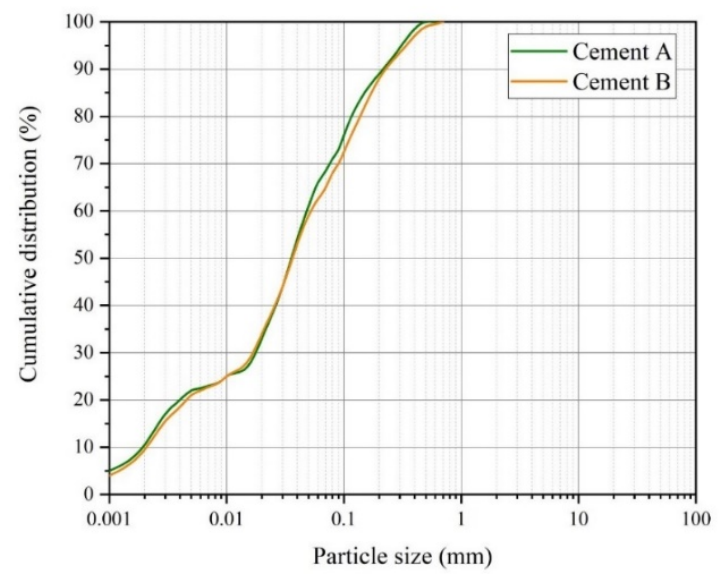

Figure 2. Particle size distribution curves of cements obtained by means of laser diffraction test.

The compositions of the concrete mixtures are shown in Table 5. The codes used to identify the concrete mixtures refer to the compressive strength class and to the used cement. For example, C40-A means a concrete of compressive strength class C40 (40 MPa) that used A cement. High w/c ratios for concretes C30-B and C40-B are observed and this influenced on compressive and splitting tensile strength results presented in next sections.

Table 5. Concrete mixtures.

\begin{tabular}{|c|c|c|c|c|c|c|}
\hline \multirow[b]{2}{*}{ Concrete } & \multicolumn{6}{|c|}{ Concrete mixtures (by weight) } \\
\hline & $\begin{array}{l}\text { Portland cement A } \\
\qquad\left(\mathrm{kg} / \mathrm{m}^{3}\right)\end{array}$ & $\operatorname{AS1}$ sand $\left(\mathrm{kg} / \mathrm{m}^{3}\right)$ & AS2 sand $\left(\mathrm{kg} / \mathrm{m}^{3}\right)$ & $\underset{\left(\mathrm{kg} / \mathrm{m}^{3}\right)}{\mathrm{AG1}}$ & $\begin{array}{c}\text { AG2 gravel } \\
\left(\mathrm{kg} / \mathrm{m}^{3}\right)\end{array}$ & w/c ratio \\
\hline C30-A & 304 & - & 875 & 325 & 720 & 0.54 \\
\hline C40-A & 393 & - & 798 & 315 & 680 & 0.45 \\
\hline \multirow[t]{2}{*}{ C50-A } & 497 & 348 & 348 & 318 & 616 & 0.41 \\
\hline & $\begin{array}{c}\text { Portland cement B } \\
\left(\mathrm{kg} / \mathrm{m}^{3}\right)\end{array}$ & BS1 sand $\left(\mathrm{kg} / \mathrm{m}^{3}\right)$ & & $\begin{array}{c}\text { BG1 gravel } \\
\left(\mathrm{kg} / \mathrm{m}^{3}\right)\end{array}$ & $\begin{array}{c}\text { BG2 gravel } \\
\left(\mathrm{kg} / \mathrm{m}^{3}\right)\end{array}$ & $\mathrm{w} / \mathrm{c}$ ratio \\
\hline C30-B & 316 & 987 & & 421 & 645 & 0.69 \\
\hline C40-B & 328 & 994 & & 515 & 601 & 0.60 \\
\hline C50-B & 491 & 1007 & & 540 & 550 & 0.41 \\
\hline
\end{tabular}

\subsection{Compressive strength}

The average compressive strength values $\left(f_{c}\right)$ are shown in Figure 3 considering the age of the tests $(3,7,28,90$ and 120 days). All concretes presented a tendency of compressive strength increase in the first days, which tended to a stabilization after 28 days. This behavior is similar to those observed in literature when using the same kind of cement, high early strength Portland cement [2], [5]. Concrete mixtures with higher w/c ratio presented lower compressive strength results, as expected.
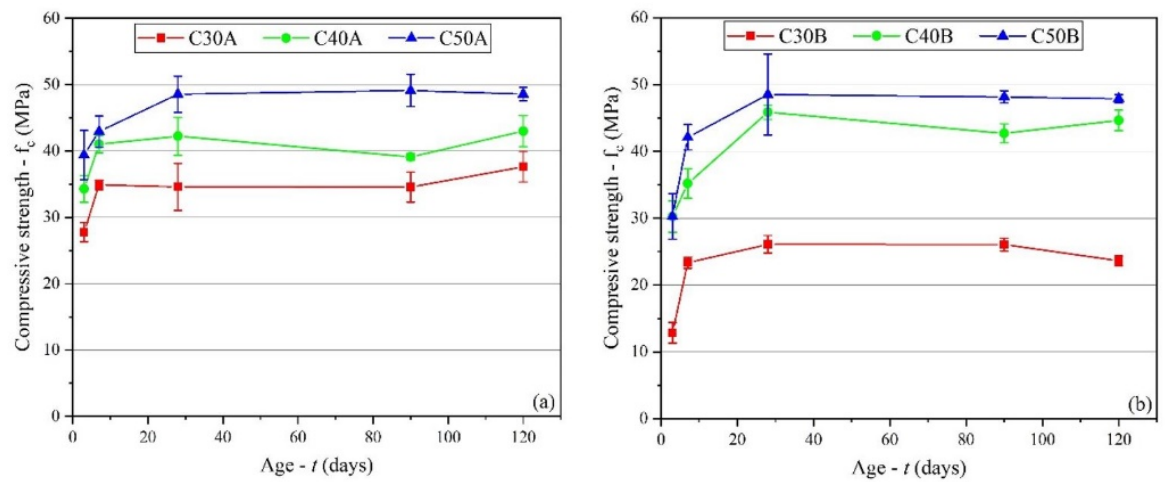

Figure 3. The evolution of average compressive strength $\left(f_{c}\right)$ with age for A concretes $(a)$ and B concretes (b) families. 
This increase tendency is explained by the fact that the compressive strength is correlated to solid/space ratio, as a consequence of Power's law [49]. The higher solid/space ratio means the more hydration products and consequently the higher concrete strength.

In Figure 3, it can be seen that some concretes did not reach the expected compressive strength at 28 days for their respective compressive strength class. However, these concretes were not discarded in the analysis carried out in the present research, since the focus of this work is on the relationship between surface electrical resistivity and compressive and splitting tensile strength, considering different concrete mixture characteristics.

\subsection{Splitting tensile strength}

The average tensile strength values $\left(\mathrm{f}_{\mathrm{t}}\right)$ are shown in Figure 4 considering the age of the tests $(3,7,28,90$ and 120 days). Similarly to compressive strength, all concretes presented an increase tendency of tensile strength in the first days, which changed to a stabilization trend after 28 days.
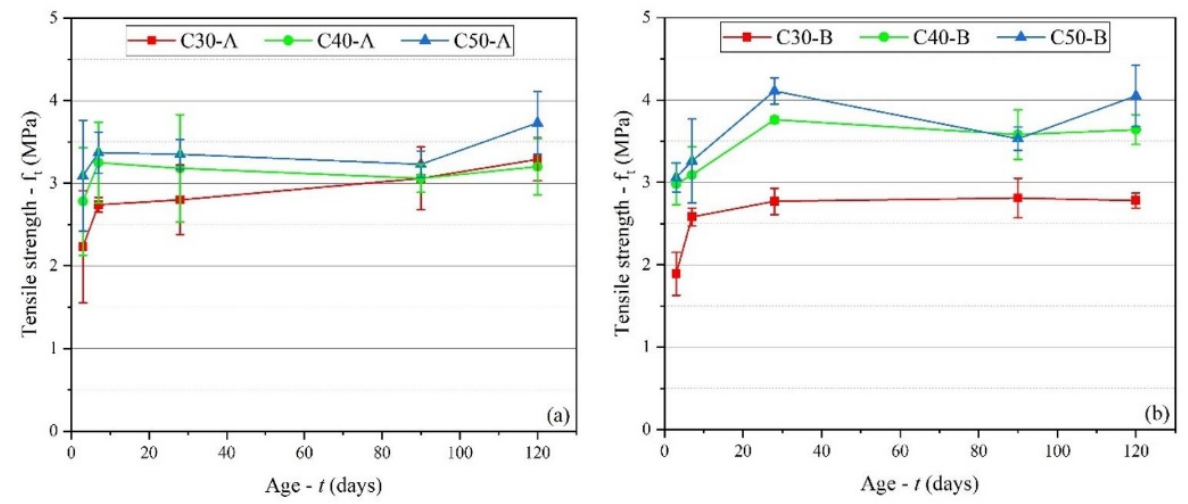

Figure 4. The evolution of average splitting tensile strength $\left(\mathrm{f}_{\mathrm{t}}\right)$ with age for A concretes (a) and B concretes (b) families.

Comparing A and B concretes (Figures 4a and $4 \mathrm{~b}$ ), a slight tendency of higher values for C40-B and C50-B concretes can be seen. The higher powder material content of AG1 gravel (see Table 5) may have contributed to a weaker interfacial transition zone in A concretes [49], which explains this behavior. However, as concrete C30-B had a significantly higher $\mathrm{w} / \mathrm{c}$ ratio, the previous aspect was not enough to overcome the influence of $\mathrm{w} / \mathrm{c}$ on splitting tensile strength and consequently it presented lower values.

\subsection{Surface electrical resistivity}

The average values of surface electrical resistivity, expressed in Figure 5, were obtained for each concrete from the measurements performed continuously on the same two specimens at the five pre-established ages $(3,7,28,90$ and 120 days). Surface electrical resistivity increases as the age and hydration level of concrete increase [28], [50]. Furthermore, there is an inverse relationship between the open porosity of concrete and surface electrical resistivity [30]. Results on this work follow this behavior and show an increase trend of resistivity along time and, in general, higher values for less porous concretes (with lower w/c ratio). This increase tendency is more pronounced in the first 28 days, where the hydration products are formed on a larger scale, specially for the kind of cement used in this research.
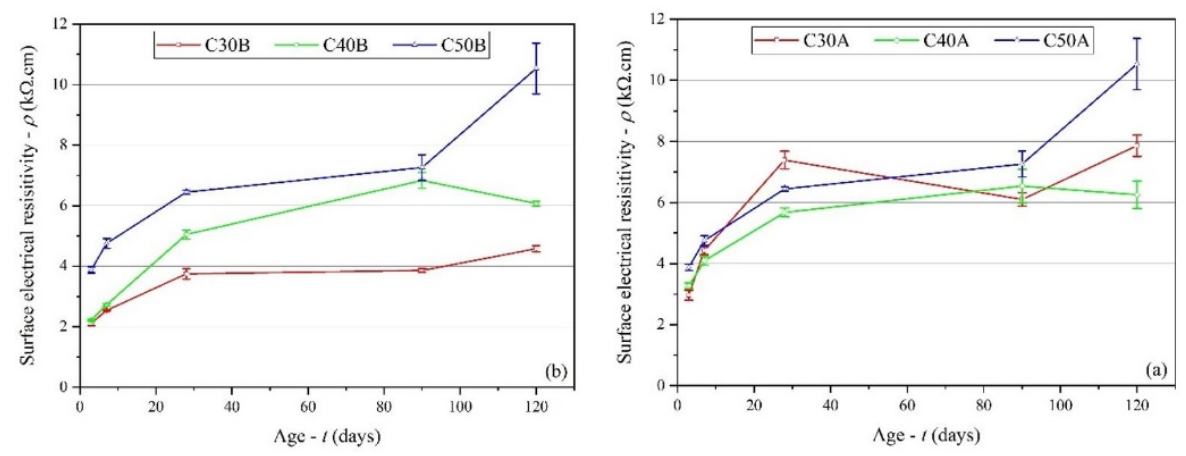

Figure 5. The evolution of average surface electrical resistivity $(\rho)$ with age for A concretes (a) and B concretes (b) families. 
Another way to analyze the evolution of surface electrical resistivity is by fitting the power function presented in Equation 1 to experimental data. In this Equation, $\rho$ is the average surface electrical resistivity, $a$ and $b$ are fitting coefficients and $t$ is the concrete age. This equation was chosen because it presented the best fitting to the experimental data, with higher determination coefficients. Fitting results are presented in Figure 6.

$$
\rho=a \cdot t^{b}
$$

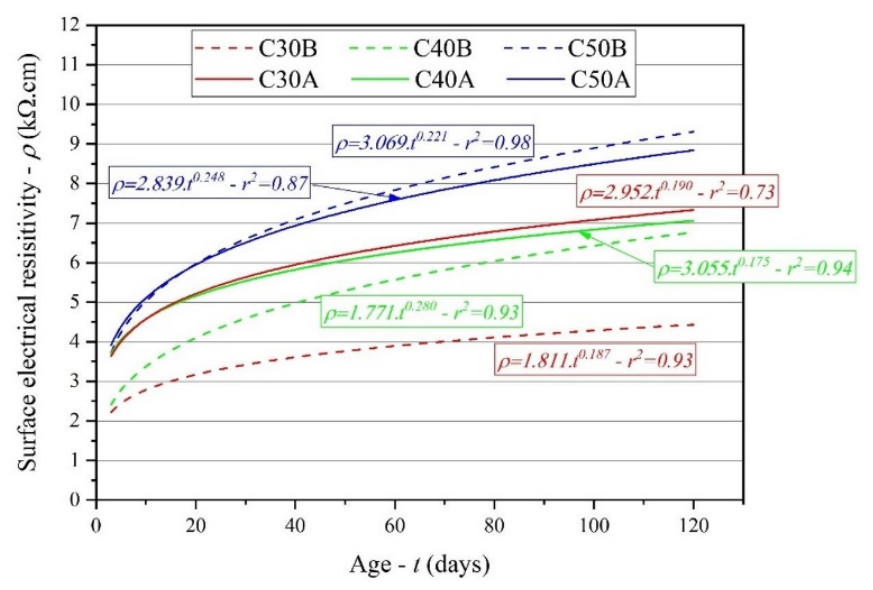

Figure 6. Fitting curves to represent the evolution of surface electrical resistivity $(\rho)$ with concrete age.

The curves presented in Figure 6 show similar growth trends for the six curves, with higher increase tendencies for less porous concretes. From Figures 5 and 6 it can be also seen that C30-A concrete presented higher values than C30-B concrete and quite close (but still slightly higher) to C40-A (Figure 6). Respect to the lower values of C30-B in comparison with C30-A, this can be explained by the higher porosity of the first concrete (Table 5). Respect to C30-A values being slightly higher than C40-A values, the behavior of C30-A concrete may be influenced by a heterogeneous distribution of coarse aggregates and the possibility of its higher presence close to the specimen's surface.

In this sense, literature shows that it is not only the paste porosity that exerts influence on the electrical resistivity measurements. Sengul [34] and Hou et al. [35] observed that the increase in the quantity of coarse aggregate and, consequently, the reduction in the cement paste content result in higher values of surface electrical resistivity. Thus, considering the possibility of a higher content of coarse aggregate close to C30-A specimen surfaces, this could explain their obtained values of surface electrical resistivity.

\subsection{Correlation between compressive strength and surface electrical resistivity}

Correlation curves between compressive strength $\left(f_{c}\right)$ and surface electrical resistivity $(\rho)$ of concrete were generated by means of nonlinear curves fitting. Initially, the experimental data were grouped into each class (C30, C40 and C50), i.e., the strength values of the $\mathrm{C} 30$-A concrete were brought together to the strength values of the $\mathrm{C} 30$ - $\mathrm{B}$ concrete and so on. This was done due to the similarity of A and B cement properties and the good harmony of data within each compressive strength class (see Figure 7). After the formation of the sets, initial fittings were performed. The choice of the best fitting function was based on the criterion of higher determination coefficient $\left(r^{2}\right)$. The $r^{2}$ results obtained for each of the curves as well as the tested functions are presented in Table 6.

Table 6 shows that the correlation curves generated by the logarithmic function are the ones that best fit the experimental data, which is in line with the literature review (Table 1). Therefore, the logarithmic function was selected to represent the relationship between concrete compressive strength $\left(f_{c}\right)$ and surface electrical resistivity $(\rho)$ in this work. During the fitting process, a statistical treatment was performed for the identification and elimination of spurious data (outliers). As a result, the correlation curves generated are presented in Figure 7. Equations 2 to 4 represent de relationships between compressive strength and surface electrical resistivity for concretes $\mathrm{C} 30, \mathrm{C} 40$ and $\mathrm{C} 50$, respectively. 


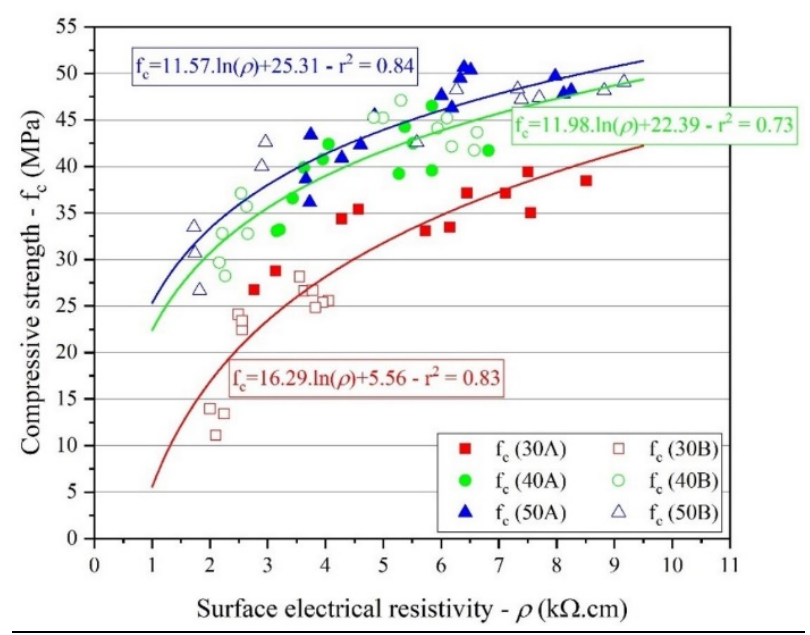

Figure 7. Correlation curves between compressive strength $\left(\mathrm{f}_{\mathrm{c}}\right)$ and surface electrical resistivity $(\rho)$ for each compressive strength class.

Table 6. Determination coefficients $\left(\mathrm{r}^{2}\right)$ of the fitting functions tested for the relationship between compressive strength $\left(\mathrm{f}_{\mathrm{c}}\right)$ and surface electrical resistivity $(\rho)$.

\begin{tabular}{cccc}
\hline Curve function & \multicolumn{3}{c}{ Coefficient of determination $\left(\mathbf{r}^{2}\right)$} \\
\cline { 2 - 4 } & $\mathbf{C 3 0}$ & $\mathbf{C 4 0}$ & C50 \\
\hline Exponential $\left(\mathrm{f}_{\mathrm{c}}=\mathrm{a}^{(\rho)}\right)$ & 0.58 & 0.53 & 0.61 \\
\hline Linear $\left(\mathrm{f}_{\mathrm{c}}=\mathrm{a} \cdot(\rho)+\mathrm{b}\right)$ & 0.67 & 0.52 & 0.63 \\
\hline Logarithmic $\left(\mathrm{f}_{\mathrm{c}}=\mathrm{a} \cdot \ln (\rho)+\mathrm{b}\right)$ & 0.83 & 0.73 & 0.84 \\
\hline Power $\left(\mathrm{f}_{\mathrm{c}}=\mathrm{a} \cdot(\rho)^{\mathrm{b}}\right)$ & 0.67 & 0.63 & 0.74 \\
\hline
\end{tabular}

$f_{c}=16.29 \ln (\rho)+5.56 \mathrm{r}^{2}=0.83(\mathrm{C} 30)$

$f_{c}=11.98 \ln (\rho)+22.39 \mathrm{r}^{2}=0.73(\mathrm{C} 40)$

$f_{c}=11.57 \ln (\rho)+25.31 \mathrm{r}^{2}=0.84(\mathrm{C} 50)$

Additionally, the experimental data were grouped in a single set and a general curve was defined regardless of the compressive strength classes of concrete, after a complementary statistical treatment, which allowed the elimination of few additional spurious data (Figure 8). Equation 5 represents this relationship. As could be expected, there was a reduction in the determination coefficient, but it still represents a good value, considering data nature.

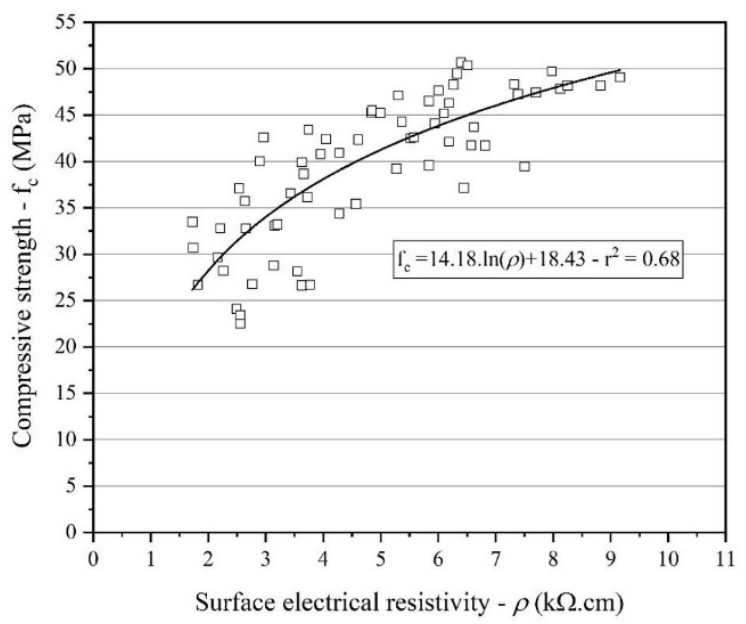

Figure 8. General correlation curve between compressive strength $\left(f_{c}\right)$ and surface electrical resistivity $(\rho)$ considering present data. 
A comparison between the curves proposed by several other authors and the proposal in this work is presented in Figure 9 (geometric correction factors for compressive strength and resistivity data were adopted when necessary). This figure shows that there is a good harmony among the curves obtained in this research and the majority of those proposed in the literature. Medeiros-Junior et al. [31] curves, as well as Ramezanianpour et al. [30], Bem et al. [9] and Sabbağ and Uyanik [28] curves are not far from those proposed in this work and Andrade and D'Andrea [27] curve covered a data range not covered by other studies. In fact, there is a region represented by the grey region in Figure 9, where most curves fit, which allows to propose a general curve to represent the behavior of all data. This general curve is represented by the function $f_{c}=11.89 \cdot \ln (\rho)+18.90$, with a determination coefficient of 0.51 (Figure 10), which seems to be acceptable for a diverse database.

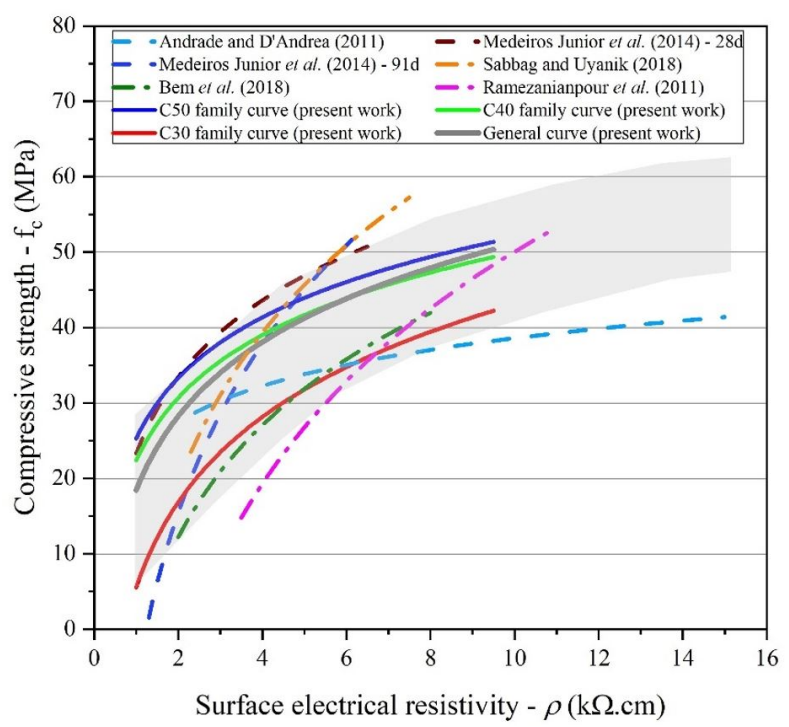

Figure 9. Comparison between correlation curves ( $\mathrm{f}_{\mathrm{c}}$ versus $\rho$ ) proposed in literature and those from this work.

There is still a lack of studies aimed in obtaining correlation curves between the concrete compressive strength and the surface electrical resistivity. During the accomplishment of this work, only few studies on this subject could be observed in literature [9], [27], [28], [31] based on the Wenner method in saturated specimens and more research in necessary to expand the literature database. At this moment, Figure 10 represents the database that could be worked on.

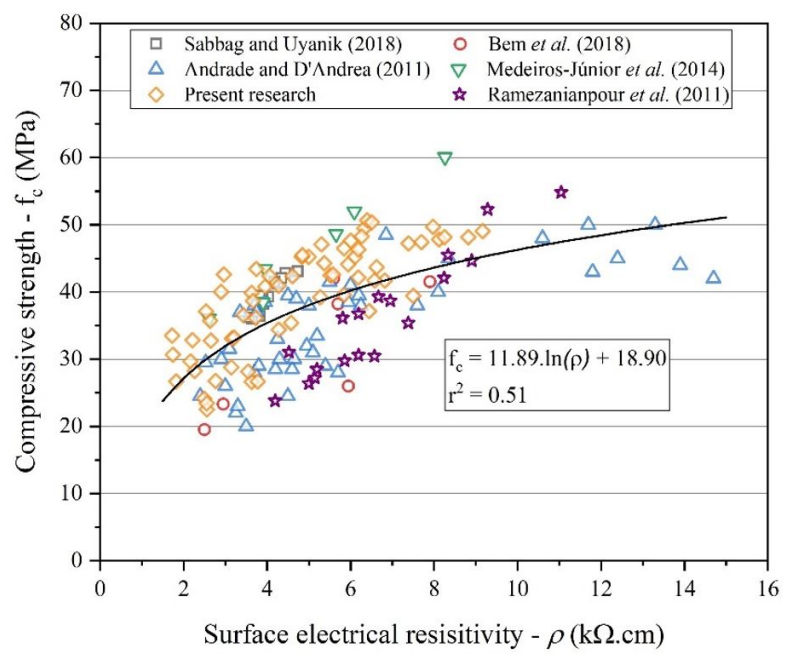

Figure 10. General correlation curve between compressive strength $\left(f_{c}\right)$ and surface electrical resistivity $(\rho)$ considering literature and present data. 


\subsection{Correlation between splitting tensile strength and surface electrical resistivity}

The correlation curves between concrete splitting tensile strength $\left(f_{t}\right)$ and surface electrical resistivity $(\rho)$ were either grouped into each compressive strength class (C30, C40 and C50). The reason for this was the same presented in previous section. The fitting procedures followed the same steps detailed in section 4.5. The obtained correlation curves are presented in Figure 11 and show that splitting tensile strength increases as surface electrical resistivity increases. This behavior is explained by the fact that both properties are dependent on the solid space relation. As more hydrated products are generated and the solid space relation increases, concrete becomes less porous. As a consequence, splitting tensile strength increases and the surface electrical resistivity, which is influenced by the lower water content in concrete porous network, becomes higher.

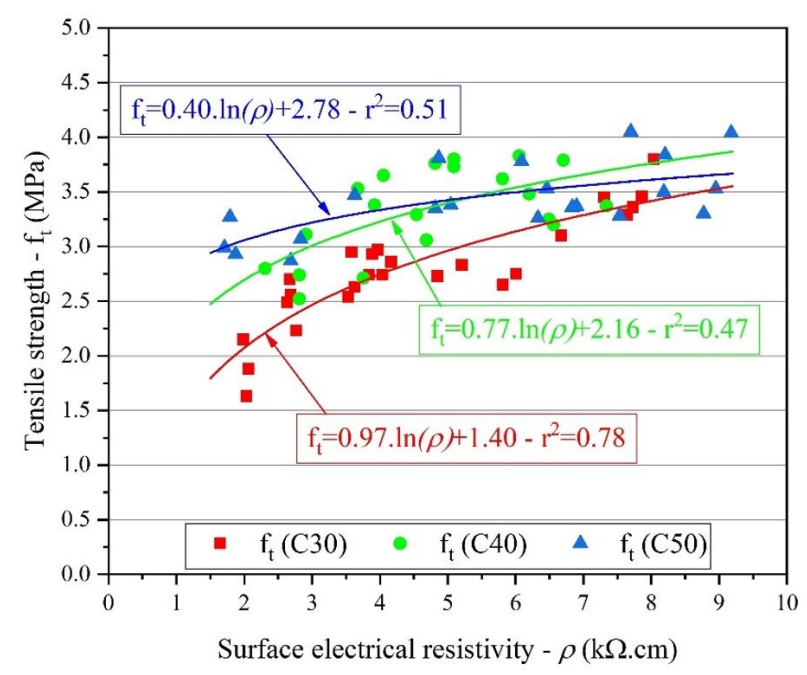

Figure 11. Correlation curves between splitting tensile strength $\left(\mathrm{f}_{\mathrm{t}}\right)$ and surface electrical resistivity $(\rho)$ for compressive strength classes C30, C40 and C50.

Equations 6 to 8 represent de relationships between splitting tensile strength and surface electrical resistivity for concretes C30, C40 and C50, respectively. They show less expressive determination coefficients than those obtained in previous section. The higher dispersion of data can be attributed to the higher dependence of tensile strength on the interfacial transition zone (ITZ) characteristics [49]. This means that there are aspects like the calcium hydroxide crystals orientation in ITZ that affect tensile strength but do not influence concrete resistivity in a similar way.

$f_{t}=0.97 \ln (\rho)+1.40 \mathrm{r}^{2}=0.78(\mathrm{C} 30)$

$f_{t}=0.77 \ln (\rho)+2.16 \mathrm{r}^{2}=0.47(\mathrm{C} 40)$

$f_{t}=0.40 \ln (\rho)+2.78 \mathrm{r}^{2}=0.51(\mathrm{C} 50)$

As it was done in previous section, the experimental data were grouped in a single set and a general curve was obtained after the fitting process (Figure 12). Equation 9 represents this relationship. As could be expected, there was a reduction in the determination coefficient, but it still represents a good value, considering data nature. No literature data on the relationship between splitting tensile strength and surface electrical resistivity for concretes could be found. 


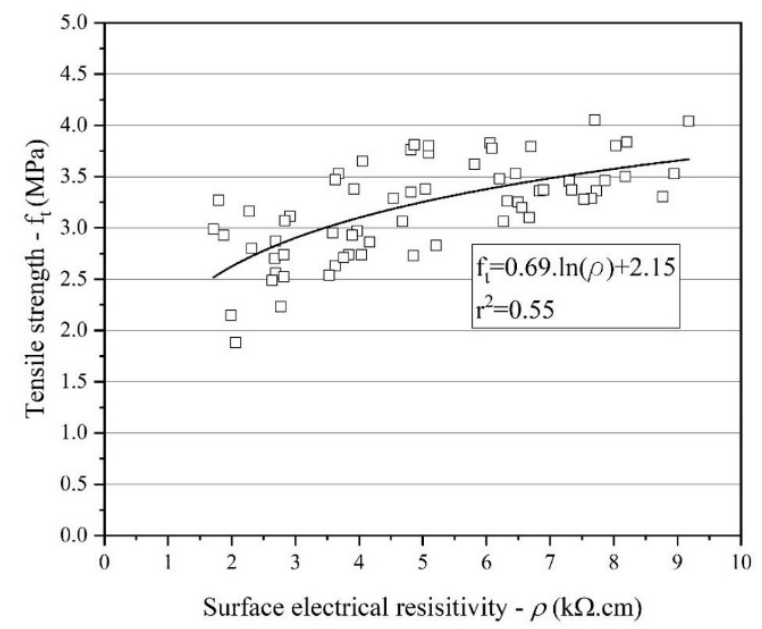

Figure 12. General correlation curve between splitting tensile strength $\left(\mathrm{f}_{\mathrm{t}}\right)$ and surface electrical resistivity $(\rho)$ considering present data.

$f_{t}=0.69 \ln (\rho)+2.15 \mathrm{r}^{2}=0.55$

\subsection{Correlation between splitting tensile strength and compressive strength}

Although the correlation between tensile strength and compressive strength was widely studied in literature [12-17] and it is not the aim of this paper, it is also presented here as part of the data analysis. Figure 13 presents this correlation, which follows a square root of compressive strength function (a particular case of the power function $\mathrm{f}_{\mathrm{t}}=a \cdot \mathrm{f}_{\mathrm{c}}^{b}$ ). As can be seen, less points were depicted in Figure 13, which is a consequence of using average results for each age and concrete mixture. In previous sections (4.5 and 4.6), individual results could be used as resistivity measurements are not destructive and were taken just before the destructive tests, resulting in more data available.

This behavior based on square root of compressive strength function is not far from that proposed by ACI [17] (also based on square root of compressive strength) and from that proposed by a Brazilian standard [16], which confirms that the relationship between tensile strength and compressive strength follows a power function as previously observed in literature [12-15].

Regarding that compressive strength at 28 days is a property regularly obtained for concretes and that surface electrical resistivity is a NDT that can be easily carried out at older ages, a relationship between splitting tensile strength $\left(\mathrm{f}_{\mathrm{t}}\right)$ and surface electrical resistivity $(\rho)$ considering the compressive strength at 28 days $\left(\mathrm{f}_{\mathrm{c} 28}\right)$ and the surface electrical resistivity at this same age $\left(\rho_{28}\right)$ is proposed (Equation 10). It is presented in Figure 14 and shows a good harmony between measured and predicted data.

$$
f_{t}=\left[0.594+0.127 \ln \left(\rho / \rho_{28}\right)\right] \cdot f_{c 28} 0.458 \mathrm{r}^{2}=0.80
$$

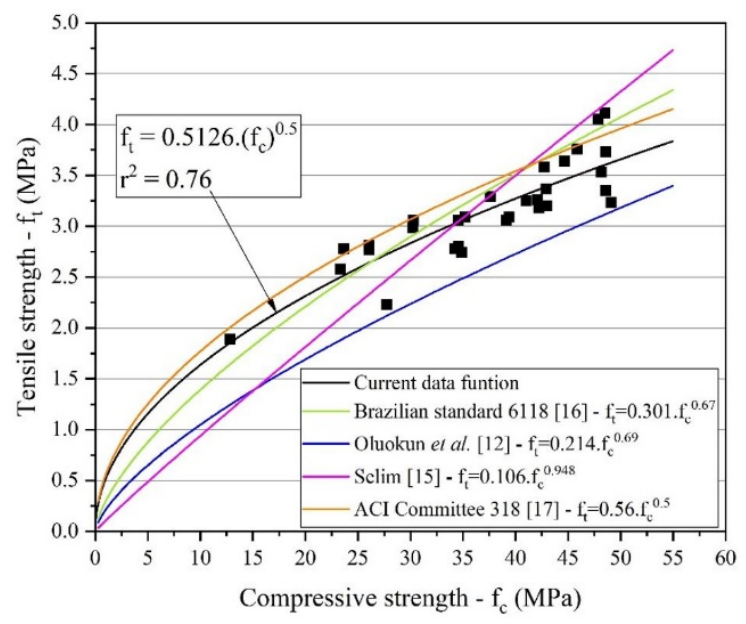

Figure 13. General correlation curve between splitting tensile strength $\left(\mathrm{f}_{t}\right)$ and compressive strength $\left(\mathrm{f}_{\mathrm{c}}\right)$ considering present data and literature correlation curves 


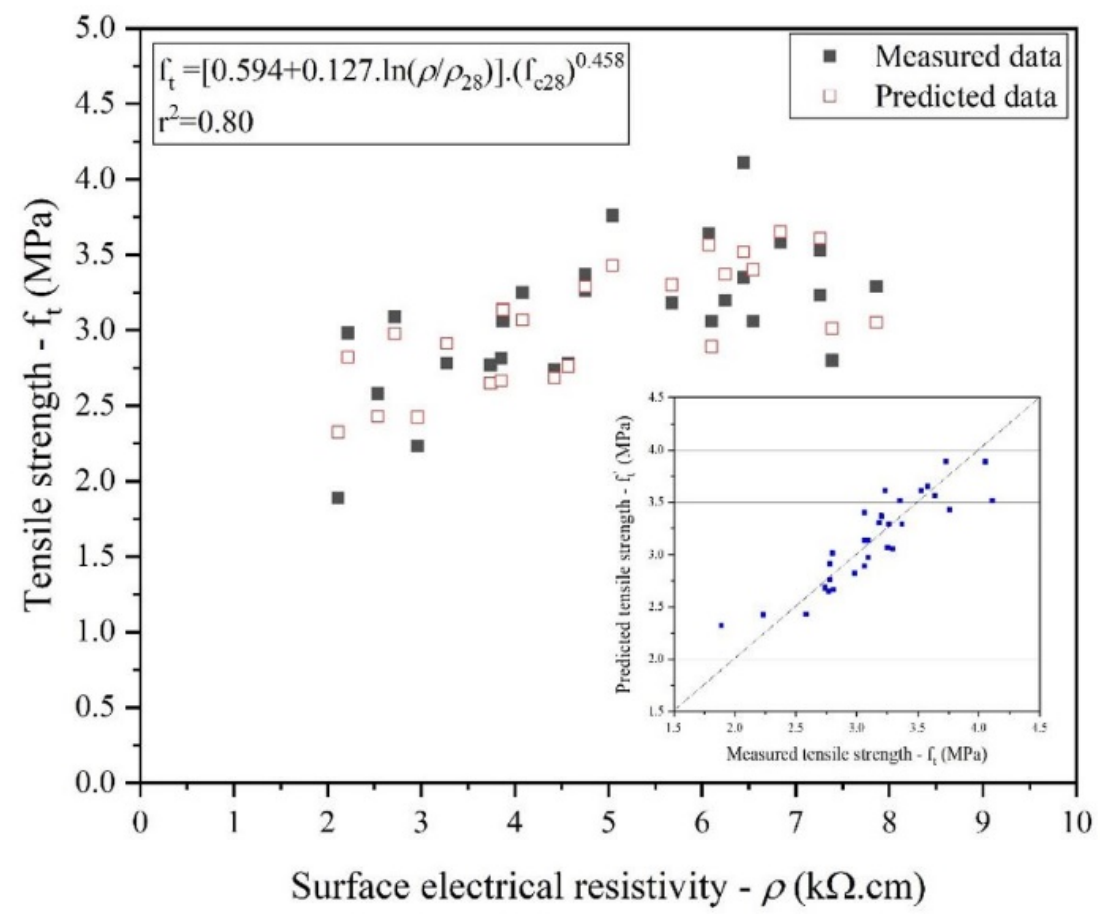

Figure 14. Relationship between splitting tensile strength $\left(\mathrm{f}_{\mathrm{t}}\right)$ and surface electrical resistivity $(\rho)$ considering the compressive strength at 28 days $\left(\mathrm{f}_{\mathrm{c} 28}\right)$ and the surface electrical resistivity at this same age $\left(\rho_{28}\right)$ for present data

\section{CONCLUSIONS}

This research obtained correlation curves between compressive strength, splitting tensile strength and surface electrical resistivity. Based on the results, the following conclusions were drawn:

a) The behavior of surface electrical resistivity measurements in relation to time presented an expected growth tendency for all concrete mixtures, as a consequence of cement paste hydration process. This increase tendency is more pronounced in the first 28 days, where the hydration products are formed on a larger scale, even more for the kind of cement used in the present research. After this age, there is a stabilization tendency;

b) To represent the relationship between compressive strength $\left(f_{c}\right)$ and surface electrical resistivity $(\rho)$ for the studied concretes, four correlation curves are proposed following logarithmic functions, being $\mathrm{f}_{\mathrm{c}}=16.29 \cdot \ln (\rho)+5.56$ indicated for C30 concrete family; $\mathrm{f}_{\mathrm{c}}=11.98 \cdot \ln (\rho)+22.39$ indicated for $\mathrm{C} 40$ concrete family; $\mathrm{f}_{\mathrm{c}}=11.57 \cdot \ln (\rho)+25.31$ indicated for C50 concrete family; and $\mathrm{f}_{\mathrm{c}}=14.18 \cdot \ln (\rho)+18.43$ indicated for the total data set. All the proposed curves provide an estimation of compressive strength of concrete, from the value of the surface electrical resistivity measured in cylindrical specimen with $10 \mathrm{~cm}$ in diameter and $20 \mathrm{~cm}$ in height. They are applicable to concretes with materials and compositions similar to those shown here and with values of compressive strength within the range from $25 \mathrm{MPa}$ to $50 \mathrm{MPa}$ at 28 days;

c) With respect to the curves achieved in this research and those found in the literature concerning the relationship between compressive strength and surface electrical resistivity obtained under the saturated dry surface condition, the few literature data available show that there is a good harmony among the curves obtained in this research and the majority of those proposed in the literature. As a result, a general correlation curve could be proposed by the function $\mathrm{f}_{\mathrm{c}}=11.89 \cdot \ln (\rho)+18.90$, which is not far from that proposed in "b" item;

d) In a similar way as compressive strength, the relationship between splitting tensile strength $\left(f_{t}\right)$ and surface electrical resistivity $(\rho)$ was represented by four correlation curves that followed logarithmic functions, being $f_{t}=0.97 \cdot \ln (\rho)+1.40$ indicated for $\mathrm{C} 30$ concrete family; $\mathrm{f}_{\mathrm{t}}=0.77 \cdot \ln (\rho)+2.16$ indicated for $\mathrm{C} 40$ concrete family; $\mathrm{f}_{\mathrm{t}}=0.40 \cdot \ln (\rho)+2.78$ indicated for C50 concrete family; and $\mathrm{f}_{\mathrm{t}}=0.69 \cdot \ln (\rho)+2.15$ indicated for the total data set. All the proposed curves provide an estimation of splitting tensile strength of concrete, from the value of the surface electrical resistivity measured in the same way and with the same validity pointed out in "b" item.

e) The relationship between splitting tensile strength $\left(\mathrm{f}_{\mathrm{t}}\right)$ and surface electrical resistivity $(\rho)$ considering the compressive strength at 28 days $\left(\mathrm{f}_{\mathrm{c} 28}\right)$ and the surface electrical resistivity at this same age $\left(\rho_{28}\right)$ can be represented by the function $\mathrm{f}_{\mathrm{t}}=\left[0.594+0.127 \ln \left(\rho / \rho_{28}\right)\right] \cdot \mathrm{f}_{\mathrm{c} 28}{ }^{0.458}$. 


\section{ACKNOWLEDGEMENTS}

The authors thank the Coordination for the Improvement of Higher Education Personnel (CAPES) for the financial support to this work. The authors also express their gratitude to the Laboratory of Tests of Materials and Structures of the UFPB (LABEME) and to the laboratory of the Research Group on Construction and Waste Materials of the IFPB (GMAT) for the availability of instruments and facilities for conducting the tests.

\section{REFERENCES}

[1] M. A. P. Irrigaray, "Estimation of the concrete compression strength by the ultrasonic pulses velocity in the concrete slurry," Ph.D. dissertation, Federal Univ. Santa Catarina, 2012.

[2] M. D. Machado, “Correlation curves to characterize concrete used in Rio de Janeiro through non - destructive tests," M.S. thesis, Federal Univ. Rio de Janeiro, Rio de Janeiro, 2005.

[3] V. M. Malhotra, "In Situ/Non-destructive Testing of Concrete - A Global Review," in Situ/Non-destructive Testing of Concrete (Special Publication SP-82). Detroit, USA: American Concrete Institute, 1984, pp. 1-16.

[4] F. R. Andriolo and B. C. Sgarboza, Concrete Inspection and Quality Control. São Paulo, Brazil, Newswork, 1993.

[5] A. C. J. Evangelista, "Evaluation of concrete strength using different non-destructive tests," Ph.D. dissertation, Federal Univ. Rio de Janeiro, 2012.

[6] K. Rashid and R. Waqas, "Compressive strength evaluation by non-destructive techniques: an automated approach in construction industry," J. Build. Eng., vol. 12, pp. 147-154, Apr. 2017. http://dx.doi.org/10.1016/j.jobe.2017.05.010.

[7] A. Lübeck, A. L. G. Gastaldini, D. S. Barin, and H. C. Siqueira, "Compressive strength and electrical properties of concrete with white Portland cement and blast-furnace slag," Cement Concr. Compos., vol. 34, pp. 392-399, Feb. 2012. http://dx.doi.org/10.1016/j.cemconcomp.2011.11.017.

[8] C. T. Chen, J. J. Chang, and W. C. Yeih, "The effects of specimen parameters on the resistivity of concrete," Constr. Build. Mater., vol. 71, pp. 35-43, Oct. 2014. http://dx.doi.org/10.1016/j.conbuildmat.2014.08.009.

[9] D. H. Bem, D. P. B. Lima, and R. A. Medeiros-Junior, "Effect of chemical admixtures on concrete's electrical resistivity," Int. J. Build. Pathol. Adaptation, vol. 36, pp. 174-187, Apr. 2018. http://dx.doi.org/10.1108/IJBPA-11-2017-0058.

[10] S. Mendes, R. Oliveira, C. Cremonez, E. Pereira, and R. A. Medeiros-Junior, "Electrical resistivity as a durability parameter for concrete design: experimental data versus estimation by mathematical model," Constr. Build. Mater., vol. 192, pp. 610-620, Dec. 2018. http://dx.doi.org/10.1016/j.conbuildmat.2018.10.145.

[11] R. A. Medeiros-Junior and M. G. Lima, "Electrical resistivity of unsaturated concrete using different types of cement," Constr. Build. Mater., vol. 107, pp. 11-16, Mar. 2016. http://dx.doi.org/10.1016/j.conbuildmat.2015.12.168.

[12] F. A. Oluokum, "Prediction of concrete tensile strength from its compressive strength: evaluation of existing relations for normal weight concrete," ACI Mater. J., vol. 88, pp. 302-309, May/Jun. 1991.

[13] M. F. M. Zain, H. B. Mahmud, A. Ilham, and M. Faizal, "Prediction of splitting tensile strength of high-performance concrete," Cement Concr. Res., vol. 32, pp. 1251-1258, 2002.

[14] C. Chhorn, S. J. Hong, and S. W. Lee, "Relationship between compressive and tensile strengths of roller-compacted concrete," J. Traffic Transp. Eng., vol. 5, pp. 215-223, 2018. http://dx.doi.org/10.1016/j.jtte.2017.09.002.

[15] P. Selim, "Experimental investigation of tensile behaviour of high strength concrete," Indian J. Eng. Mater. Sci., vol. 15, pp. 467-472, 2008.

[16] Associação Brasileira de Normas Técnicas, Design of structural concrete - Procedure, 2003.

[17] ACI Committee 318, Building code requirements for structural concrete (ACI 318-11) and commentary. Farmington Hills: American Concrete Institute, 2011.

[18] G. M. Barrow, Physical Chemistry. Barcelona, Spain: Reverté, 1964.

[19] R. Polder et al., "Test methods for on site measurement of resistivity of concrete," Mater. Struct., vol. 33, pp. 603-611, 2000. http://dx.doi.org/10.1007/BF02480599.

[20] Spanish Association for Standardisation and Certification, Concrete durability: Determination of the electrical resistivity. Part1: Direct test (reference method), UNE 83988-1, AENOR, Madrid, Spain, 2008.

[21] Associação Brasileira de Normas Técnicas, Concrete hardened - Determination of electrical-volumetric resistivity - Test method, ABNT NBR 9204, 2012.

[22] ASTM International, Standard Test Method for Bulk Electrical Resistivity or Bulk Conductivity of Concrete, C1876, 2019.

[23] L. Santos, "Evaluation of the electrical resistivity of concrete as a parameter for the prediction of the initiation of corrosion induced by chlorides in concrete structures," M.S. thesis, University of Brasília, Brasília, DF, 2006.

[24] F. Wenner, "A Method of measuring earth resistivity," Bull. Bur. Stand., vol. 12, pp. 469-478, 1915.

[25] A. G. Abreu, "Effect of Mineral Additions on the Electrical Resistivity of Conventional Concretes," M.S. thesis, Federal University of Rio Grande do Sul, 1998. 
[26] P. Azarsa and R. Gupta, "Electrical Resistivity of Concrete for Durability Evaluation: A Review," Adv. Mater. Sci. Eng., vol. 2017, pp. 1-30, May 2017. http://dx.doi.org/10.1155/2017/8453095.

[27] C. Andrade and R. D'Andrea, "The electrical resistivity as a control parameter of the concrete and its durability," J. ALCONPAT, vol. 1, pp. 90-98, 2011.

[28] N. Sabbağ and O. Uyanık, "Determination of the reinforced concrete strength by apparent resistivity depending on the curing conditions," J. Appl. Geophys., vol. 155, pp. 13-25, Feb. 2018. http://dx.doi.org/10.1016/j.jappgeo.2018.03.007.

[29] X. Wei, L. Xiao, and Z. Li, "Prediction of standard compressive strength of cement by the electrical resistivity measurement," Constr. Build. Mater., vol. 31, pp. 341-346, Jun. 2012. http://dx.doi.org/10.1016/j.conbuildmat.2011.12.111.

[30] A. Ramezanianpour, A. Pilvar, A. Mahdikhani, and F. Moodi, "Practical evaluation of relationship between concrete resistivity, water penetration, rapid chloride penetration and compressive strength," Constr. Build. Mater., vol. 25, no. 5, pp. $2472-2479,2011$. http://dx.doi.org/10.1016/j.conbuildmat.2010.11.069.

[31] R. A. Medeiros-Junior, M. G. Lima, M. H. F. Medeiros, and L. V. Real, "Investigation of the compressive strength and electrical resistivity of concrete with different types of cement," J. ALCONPAT, vol. 4, pp. 113-128, 2014.

[32] W. Morris, E. I. Moreno, and A. A. Sagués, "Practical evaluation of resistivity of concrete in test cylinders a Wenner array probe," Cement Concr. Res., vol. 26, pp. 1779-1787, Dec. 1996. http://dx.doi.org/10.1016/S0008-8846(96)00175-5.

[33] M. H. F. Medeiros, "Study of variables that influence the resistivity measurements of reinforced concrete structures," Civ. Eng. J. Univ. Minho, vol. 12, pp. 55-64, 2001.

[34] O. Sengul, "Use of electrical resistivity as an indicator for durability," Constr. Build. Mater., vol. 73, pp. 434-441, Dec 2014. http://dx.doi.org/10.1016/j.conbuildmat.2014.09.077.

[35] T. Hou, V. K. Nguyen, Y. Su, Y. Chen, and P. Chen, "Effects of coarse aggregates on the electrical resistivity of Portland cement concrete," Constr. Build. Mater., vol. 133, pp. 397-408, Feb. 2017. http://dx.doi.org/10.1016/j.conbuildmat.2016.12.044.

[36] Associação Brasileira de Normas Técnicas, Aggregates - Determination of the granulometric composition, ABNT NBR NM $248,2003$.

[37] Associação Brasileira de Normas Técnicas, Aggregates - Determination of bulk density and volume of voids, ABNT NBR NM 45, 2006.

[38] Associação Brasileira de Normas Técnicas, Fine aggregate - Determination of specific weight and bulk density, ABNT NBR NM 52, 2009.

[39] Associação Brasileira de Normas Técnicas, Coarse aggregate - Determination of density, apparent density and water absorption, ABNT NBR NM 53, 2009.

[40] Associação Brasileira de Normas Técnicas, Aggregates - Determination of fine material passing through the 75 um sieve per wash, ABNT NBR NM 46, 2003.

[41] Associação Brasileira de Normas Técnicas, Portland cement and other powdered materials - Determination of specific mass, ABNT NBR 16605, 2017.

[42] Associação Brasileira de Normas Técnicas, Portland cement and other powdered materials - Determination of fineness by the air permeability method (Blaine method), ABNT NBR 16372, 2015.

[43] Associação Brasileira de Normas Técnicas, Concrete - Procedure for casting and curing of specimens, ABNT, 2016.

[44] Associação Brasileira de Normas Técnicas, Concrete - Sampling of fresh concrete, ABNT NBR NM 33, 1998.

[45] Asociacion Espanola de Normalizacion, Concrete durability: Determination of the electrical resistivity. Part1: Four-points or Wenner method, UNE 83988-2, 2014.

[46] Associação Brasileira de Normas Técnicas, Concrete - Compression test of cylindrical specimens, ABNT NBR 5739, 2007.

[47] Associação Brasileira de Normas Técnicas, Concrete and mortar - Determination of the tensile strength by diametrical compression of cylindrical test specimens, ABNT NBR 7222, 2011.

[48] Associação Brasileira de Normas Técnicas, Concrete aggregates - Specification, ABNT NBR 7211, 2009.

[49] P. K. Mehta and P. J. M. Monteiro, Concrete: Microstructure, Properties, and Materials, 3rd ed. New York, NY, USA: McGraw-Hill, 2006.

[50] P. Ghosh and Q. Tran, "Influence of parameters on surface resistivity of concrete," Cement Concr. Compos., vol. 62, pp. 134-145, Jul. 2015.

Author contributions: CCA: experimental work, formal analysis, writing; GRM: conceptualization, funding acquisition, supervision, formal analysis, writing.

Editors: David Oliveira, Guilherme Aris Parsekian. 